\title{
Daylighting Performance in Balai Padang Adat House at South Borneo
}

\author{
Febby R. Masruchin ${ }^{1}$, I Gusti Ngurah Antaryama ${ }^{1}$, Sri Nastiti N. Ekasiwi ${ }^{1}$, and Desak P. Damayanti ${ }^{2}$
}

\begin{abstract}
Balai Padang Adat is one of the traditional building in tropical area. The characteristic of this building is large, long and deep dimention but it has limited area of the openings. Field meassurement for 3 days and 3 times (09.00, $12.00,15.00)$ is used to identify factors that affect daylighting performance. This research found that daylighting performance was in poor quality. The outdoor illumination is very high which reached 100.000 lux caused by latitude, altitude and cloud cover. The latitude is $2^{\circ}$ in the south from the equator's line and the altitude is 450 meters above sea level which close from the sun. The cloud cover is minimum lower than 40\%. The indoor illumination can reach 1 lux as the lowest level during the day caused by obstruction, overhang, shape and space of the building, material reflectance, area and position of the openings. There is a building in the west and east and a vegetation in the south as an obstruction. This building has a large dimention with double layer room, but it has minimum material reflectance of the wall and floor. This building has a minimum area of the openings, high position of the openings near the overhangs and also long dimention of the overhang. Meassurement was done in Laras-Pematang room as a living room and Bilik room as a bedroom and kitchen. Overall, daylighting performance of this building can not meet standart activity such as illumination value, daylighting factors and daylighting distribution from morning to the evening.
\end{abstract}

Keywords-Balai Adat Padang House, Daylighting, Traditional Building, Tropical Climate

\section{INTRODUCTION}

Balai Padang Adat House at South Borneo is one of the traditional building inhabited by Dayak Meratus people. It is located in the tropical area that has a large potention of daylighting for passive systems of lighting from morning to evening (figure 1). Balai Padang Adat House is the biggest one on the map and small building around is the housing of each family.

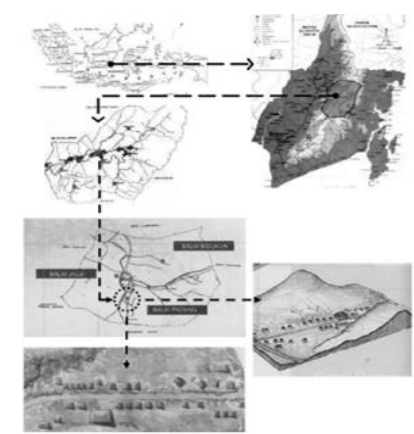

Figure 1. Balai Padang Adat House Location

${ }^{1}$ Febby R. Masruchin, I Gusti Ngurah Antaryama, Sri Nastiti N. Ekasiwi are with Departement of Architecture, Institut Teknologi Sepuluh Nopember, Surabaya, 60111, Indonesia. E-mail: febbyrahmatullah@gmail.com; nastiti@arch.its.ac.id.

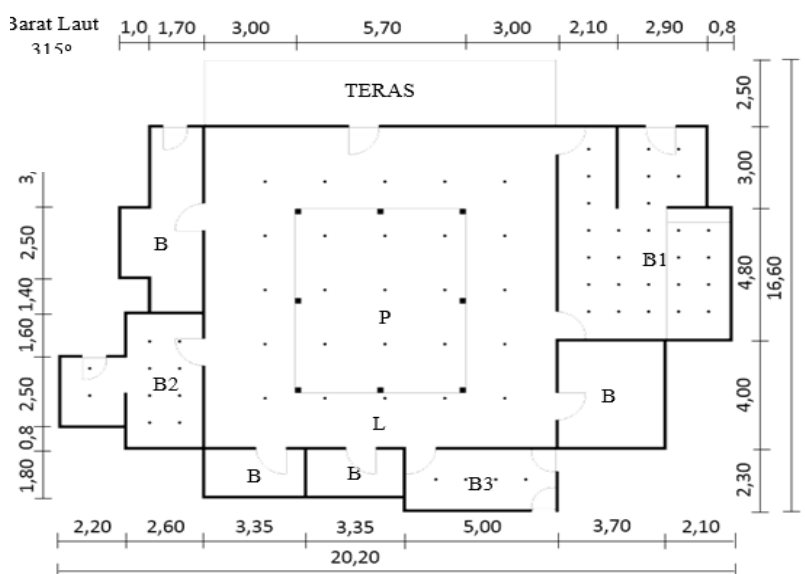

Figure 2. Balai Padang Adat House Plan
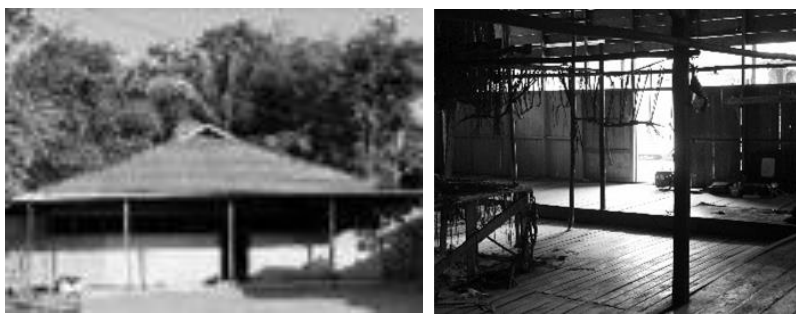

Figure 3. Daylighting Condition in Balali Padang Adat House

Balai Padang Adat House has a large, long and deep dimension with double layer room (figure 2), but has only minimal openings between the wall and the roof extends from end to end of the wall and hight opening (figure 3) which does not required with previous research minimum WWR 20\% and high recomendation up to work plan 1,7 meters [16].

This research is important because there is a different activity of the occupant in the last and present. The design was adapted to the conditions of past occupants which did activity out of the building from morning (06.00 AM) to the evening (18.00 PM) because all of the people worked in the fields that has a far location from this building [9]. In the present, occupants do many activity in the building from morning to evening. Now, there are only traditional ceremonies every year and people does not live in this building because there are many part of the building is broken. But there are potention to reuse this building if it has been repaired.

Balai Padang Adat House is located in 2029'59" $2^{\circ} 56^{\prime} 10^{\prime \prime}$ south latitude, highlands area 450 meters above sea level and has a distance 138 kilometers from the city. There are 3 tipes of Balai Adat in South Borneo, Balai Padang, Balai Jalai and Balai Bidukun [9]. They have different characteristics related Building and openings.

${ }^{2}$ Desak Putu Damayanti with Research Institute for Human Settlement - Ministry of Public Work, Denpasar, Indonesia. E-mail damabalaipu@gmail.com 
Balai Bidukun and Jalai have openings on the roof as a toplighting strategy.

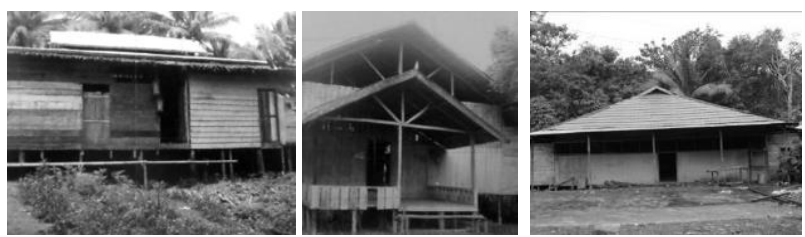

Figure 4. Balai Adat House. Bidukun Type (Left), Jalai Type (Centre) and Padang Type (Right)

Building in tropical climate has 2 design strategy related openigs, toplighting and sidelighting [7]. There are 4 component of toplighting, clerestoriy, monitor, sawtooth and skylight. This strategy is used in large building and has a long depth. Sidelighting can be used in small building because it can not reach area far from the openings. There are 3 factors that affect sidelighting strategy, shape, area and opening position [14]. Increasing opening area or window to wall ratio (WWR) can increase daylight faactors. Increasing opening postition can increase daylight factors. Vertical shape of the openings is better than horizontal shape. In the previous research, increasing $10 \%$ openings area can increase $7 \%$ illumination value. Better recomendation of opening area is $20 \%$ related to the previous research [15]. Better recommendation for openings position is 2.7 to 3 meters of upper opening and 1 meters or lower openings [16]

There are several factors that support daylighting performance related share, area and opening position. They are overhang, material reflectance, shape and dimention of the building and obstruction [7]. If the overhang is getting longer, it can decrease daylighting performance. Increasing 0.7 meters length of overhang can decrease $8 \%$ illumination and 2 meters can decrease $25 \%$ [10]. Minimum ratio length of overhang and high of the opening is $1: 1.2$ for better daylighting performance. Material reflectance affect daylighting distribution inside the building. Using low material reflectance can decrease illumination value $33 \%$ for wall, $33 \%$ for floor and $51 \%$ for ceiling [5]. Dimention of building related floor area and depth. Larger room affect decreasing daylighting performance because daylight can not distribute evenly. Obstruction such us trees and buildings can minimize daylighting enter into the reoom. Factors related obstruction is distance and high of the obstruction.

Sun as a source of natural lighting can be devided into 3 types, daylight, sunlight and reflected light. Tropics area is dominated by daylight and overcast sky condition 10.000 lux. Location of the object determine the latitude and altitude that can affect illumination level outside the building before enter to the buildings.

\section{METHOD}

This research use field meassurement to identify daylighting performance on Balai Padang Adat and factors that affect it. The dependent variable related to the quantity of illumination value, Daylighting Factors (DF) and daylighting distribution. Result of illumination value is compared with standard illumination [12], result of daylight factors is compared with standard daylight factors [6] and result of daylighting distribution is compared with first standart [1] and second standard [13] to identify dalighting performance related present occupant activity. Field meassurement can be devided into 2 stages. First stage is meassuring geometry of the building and second stage is meassuring daylighting. Field meassurement did on dry season (April to October) at 3 days and 3 times [13] (table 1).

TABLE 1.

MEASSUREMENT TIME

\begin{tabular}{ccccc} 
No & Date & Time 1 & Time 2 & Time 3 \\
\hline 1 & $12-08-2015$ & 09.00 & 12.00 & 15.00 \\
2 & $13-08-2015$ & 09.00 & 12.00 & 15.00 \\
3 & $14-08-2015$ & 09.00 & 12.00 & 15.00 \\
\hline \hline
\end{tabular}

Daylighting meassurement did indoors (figure 5) and outdoors (figure 6). Meassurement is using lux meter tools with a LX1010BS model that has a $4 \%$ accuration for illumination lower than 10.000 lux and $5 \%$ for illumination upper than 10.000 lux. Indoor meassurement take place in 4 room and use TUU and TUS [11] and grid pattern every 1 meters in Bilik rooms and every 2 meters in Laras-Pematang rooms (figure 2). Total meassurement spot in each room shown in table 2 .
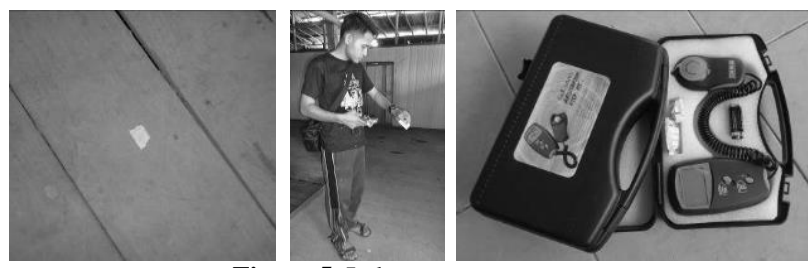

Figure 5. Indoor meassurement
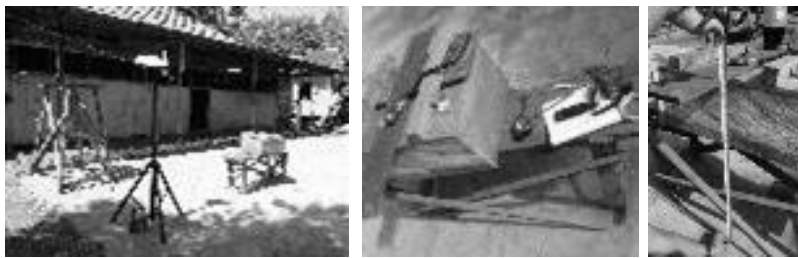

Figure 6. Outdoor meassurement

TABLE 2.

MEASSUREMENT SPOT IN ROOMS

\begin{tabular}{cc}
\hline \hline Room & Total Meassurement Spot \\
\hline Laras-Pematang (LP) & 24 spot every 2 meters \\
Bilik 1 (B1) & 28 spot every 1 meters \\
Bilik 2 (B2) & 9 spot every 1 meters \\
Bilik 3 (B3) & 4 spot every 1 meters \\
\hline \hline
\end{tabular}

\section{RESULTS AND DISCUSSION}

\section{A. Occupant activity}

Based on the observation, occupant did not live in Balai Padang Adat because there are many part of the building is broken. One of the exampple in Bilik floor is caused by bamboo material. Now, they lived in their homes around Balai Padang Adat House. Balai Padang Adat House is lived by people 1 week before ceremony and when it happen. There are traditional ceremonies every year tak place in Balai Padang Adat House. 
Occupants did activity and lived in their own house shown in Table 3.

In the past, occupant did activity outside the building. Now, occupants do many activity inside the building. There are 3 factors that affect it, livelyhood systems, education and family member (Table 4).

\section{B. Sky and cloud cover Condition}

First and third day show outdoor illumination value is high because overcast condition of cloud cover. At the first day cloud cover condition at 09.00 and 15.00 is 40 $60 \%, 0-10 \%$, at 12.00 is $0-10 \%$. At the second day, cloud cover condition at 09.00 until 15.00 is $80-100 \%$ (Figure 7 ). Third day show result as same as the first day.

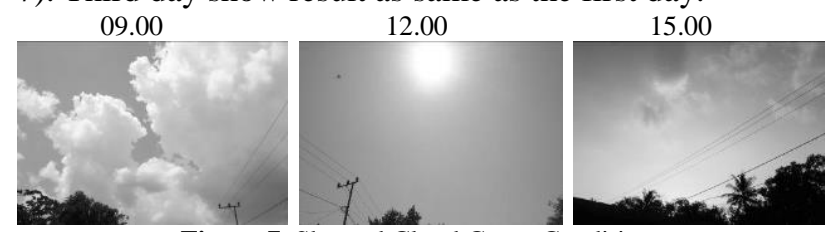

Figure 7. Sky and Cloud Cover Condition

\section{Outdoor Illumination value result}

Outdoor illumination value show a high value in 3 days and 3 times. Minimum value is 11.400 lux at $15.00 \mathrm{PM}$ and maximum value is 109.500 lux at 12.00 AM. Average outdoor illumination value for 3 days is shown in figure 5 below. First day and third day show the same pattern is caused by minimum cloud cover condition in first and third day.

\section{Indoor Illumination value result}

Indoor illumination value show a low value in LarasPematang room, Bilik 1 room, Bilik 2 room and Bilik 3 room altough outdoor illumination value is very high. Average indoor illumination value for 3 days in each room shown in table 6, 7 and 8 below. Illumination standart for Laras-Pematang room as a living room is 120-250 lux, 120-250 lux for Bilik as a bedroom and 250 lux for Bilik as a kitchen [12].

TABLE 3.

OCCUPANT ACTIVITY IN ROOMS ALL DAY

\begin{tabular}{cccccccccccccccccc}
\hline \hline Time & 01.00 & 02.00 & 03.00 & 04.00 & 05.00 & 06.00 & 07.00 & 08.00 & 09.00 & 10.00 & 11.00 & 12.00 \\
Rooms & B & B & B & B & A & A & A & L & L & L & B-L & B-L \\
\hline \hline Time & 13.00 & 14.00 & 15.00 & 16.00 & 17.00 & 18.00 & 19.00 & 20.00 & 21.00 & 22.00 & 23.00 & 24.00 \\
Rooms & B-L & B-L & L & A & L-K & L-K & L-K & L-K & B-L & B & B & B \\
\hline \hline
\end{tabular}

(A) All, (B) Bedroom, (L) Livingroom, (K) Kitchen

TABLE 4.

FACTORS RELATED OCCUPANT ACTIVITY

\begin{tabular}{|c|c|c|}
\hline Factors & Past Activity & Present Activity \\
\hline Livelyhood Systems & Just farming on the field far from home & Many job and they can do it at home \\
\hline Education & $\begin{array}{l}\text { Children was not going to school, but help their } \\
\text { parents to the field }\end{array}$ & $\begin{array}{l}\text { Children go to school and do their home work from } \\
\text { afternoon to evening at home }\end{array}$ \\
\hline Family Members & $\begin{array}{c}\text { Few members, nobody stay at home from morning } \\
\text { to the evening }\end{array}$ & $\begin{array}{l}\text { A lot of members, several members go to the field and } \\
\text { the other do other job at home }\end{array}$ \\
\hline
\end{tabular}

TABLE 5.

OUTDOOR ILLUMINATION

\begin{tabular}{ccccc}
\hline \hline & Value & 09.00 & 12.00 & 15.00 \\
\hline \multirow{2}{*}{ First day } & Max & 93.500 & 109.500 & 30.500 \\
& Average & 90.500 & 107.300 & 25.900 \\
& Max & 36.000 & 64.100 & 16.700 \\
Second & Min & 24.100 & 37.400 & 11.400 \\
& Average & 27.500 & 49.800 & 13.100 \\
& Max & 67.500 & 108.000 & 18.500 \\
& Min & 45.900 & 106.400 & 13.300 \\
Third day & Average & 54.600 & 106.900 & 16.100 \\
\hline \hline
\end{tabular}

TABLE 6.

INDOOR ILLUMINATION AT LARAS-PEMATANG

\begin{tabular}{cccc}
\hline \hline Time & Average & Maximum & Minimum \\
\hline 09.00 & 25,2 lux & 83 lux & 3,5 lux \\
12.00 & 36,4 lux & 93 lux & 8,5 lux \\
15.00 & 26,8 lux & 165 lux & 1 lux \\
\hline \hline
\end{tabular}

TABLE 7.

INDOOR ILLUMINATION AT BILIK 1

\begin{tabular}{cccc} 
& \multicolumn{4}{c}{ INDOOR ILLUMINATION AT BILIK 1 } \\
\hline \hline Time & Average & Maximum & Minimum \\
\hline 09.00 & 20,39 lux & 171 lux & 6,5 lux \\
12.00 & 57,81 lux & 389 lux & 9 lux \\
15.00 & 15,42 lux & 190 lux & 1 lux \\
\hline \hline
\end{tabular}

TABLE 8.

INDOOR ILLUMINATION AT BILIK 2

\begin{tabular}{cccc} 
& \multicolumn{4}{l}{ INDOOR ILLUMINATION AT BILIK 2 } \\
\hline \hline Time & Average & Maximum & Minimum \\
\hline 09.00 & 2,06 lux & 4 lux & 1 lux \\
12.00 & 2,94 lux & 3,5 lux & 2,5 lux \\
15.00 & $0,94 \operatorname{lux}$ & 2,5 Lux & $0,5 \operatorname{lux}$ \\
\hline \hline
\end{tabular}


TABLE 9.

INDOOR ILLLUMINATION AT BILIK 3

\begin{tabular}{cccc}
\hline \hline Time & Average & Maximum & Minimum \\
\hline 09.00 & 28,75 lux & 64,5 lux & 5,5 lux \\
12.00 & 67,25 lux & 193,5 Lux & 12 lux \\
15.00 & 11 lux & 23 Lux & 2 lux \\
\hline \hline
\end{tabular}

Average illumination value in Laras-Pematang room as a living room is not meet illumination standart (120250 lux), Bilik 1, Bilik 2 and Bilik 3 room is also not meet standart illumination for as a bedroom (120-250 lux) and as a kitchen (250 lux). Maximum value take in several spot in room that is located near the openings or the door. Based illumination standard, design of Balai Padang Adat house is not meet standard for present occupant activity.

\section{E. Daylight Factors result}

Daylight factors show a low persentage in LarasPematang room, Bilik 1 room, Bilik 2 room and Bilik 3 room. Average Daylight Factors for 3 days in each room shown in table 9 below. Daylight Factor standard for Laras-Pematang room as a living room is $1,5 \%, 1 \%$ for Bilik as a bedroom and $2 \%$ for Bilik as a kitchen [6].

TABLE 10.

DAYLIGHT FACTORS AT LARAS-PEMATANG

\begin{tabular}{ccccc}
\hline \hline Function & Time & Average & Max & Min \\
\hline Living & 09.00 & $0,07 \%$ & $0,20 \%$ & $0,01 \%$ \\
room & 12.00 & $0,06 \%$ & $0,21 \%$ & $0,006 \%$ \\
& 15.00 & $0,10 \%$ & $0,35 \%$ & $0 \%$ \\
\hline \hline
\end{tabular}

TABLE 11.

DAYLIGHT FACTORS AT BILIK 1

\begin{tabular}{ccccc}
\hline \hline Function & Time & Average & Max & Min \\
\hline Bed room & 09.00 & $0,04 \%$ & $0,41 \%$ & $0 \%$ \\
& 12.00 & $0,03 \%$ & $0,26 \%$ & $0,002 \%$ \\
& 15.00 & $0,05 \%$ & $0,58 \%$ & $0 \%$ \\
Kitchen & 09.00 & $0,03 \%$ & $0,09 \%$ & $0,007 \%$ \\
& 12.00 & $0,04 \%$ & $0,09 \%$ & $0,01 \%$ \\
& 15.00 & $0,02 \%$ & $0,08 \%$ & $0,006 \%$ \\
\hline \hline
\end{tabular}

TABLE 12.

DAYLIGHT FACTORS AT BILIK 2

\begin{tabular}{ccccc}
\hline \hline Function & Time & Average & Max & Min \\
\hline Bed room & 09.00 & $0,004 \%$ & $0,01 \%$ & $0 \%$ \\
& 12.00 & $0,009 \%$ & $0,01 \%$ & $0,007 \%$ \\
& 15.00 & $0,004 \%$ & $0,008 \%$ & $0 \%$ \\
Kitchen & 09.00 & $0,003 \%$ & $0,003 \%$ & $0,003 \%$ \\
& 12.00 & $0,006 \%$ & $0,006 \%$ & $0,006 \%$ \\
& 15.00 & $0 \%$ & $0 \%$ & $0 \%$ \\
\hline \hline
\end{tabular}

Table 13.

Daylight factors at bilik 3

\begin{tabular}{ccccc}
\hline \hline Function & Time & Average & Max & Min \\
\hline Living & 09.00 & $0,06 \%$ & $0,09 \%$ & $0,02 \%$ \\
room & 12.00 & $0,05 \%$ & $0,13 \%$ & $0,01 \%$ \\
& 15.00 & $0,03 \%$ & $0,07 \%$ & $0,01 \%$ \\
\hline \hline
\end{tabular}

Daylight Factor is a resultan of SC (Sky Component), ERC (External Reflected Component) and IRC (Internal Reflected Component) [15]. we can find Daylight Factor use calculation persentage of indoor illumination value to outdoor illumination value [15]. as the result, Daylight Factors in this case is very low because indoor illumination is very low but outdoor illumination is very high. Average Daylight Factors in Laras-Pematang room as a living room is not meet standart $(1,5 \%$ Bilik 1 , Bilik 2 and Bilik 3 room is also not meet standart as a bedroom (1\%) and as a kitchen (2\%)

Balai Padang Adat house has a worse Daylighting Performance from the result of illumination value and Daylight Factors which not meet standart for activity. We can see the performance from figure 3. Left picture show out of the building is very bright and we can not see inside the building from the dark colour in openings and doors. Centre and right picture show condition in LarasPematang room and Bilik room is dark.

\section{F. Distribution of daylighting performance result}

Indoor illumination and Daylight Factor is used to identify performance related to the activity in every room. Distribution of daylight is used to identify performance when light enter to the room. Daylight distribution is identified by 2 standart. First standart in table 14 to identify persentage area in the room that meet standart of illumination [1]. Second standart in table 15 to identify the possibility of glare which calculated from comparison of minimum illumination to average illumination value [13]

TABLE 14.

DAYLIGHTING DISTRIBUTION (1ST STANDARD)

\begin{tabular}{cccc}
\hline \hline Room & Time & Value & Meassurement Spot \\
\hline Laras-P & 09.00 & $0 \%$ & 0 from 24 spot \\
& 12.00 & $0 \%$ & 0 from 24 spot \\
& 15.00 & $0 \%$ & 0 from 24 spot \\
Bilik 1 & 09.00 & $4 \%$ & 1 from 28 spot \\
& 12.00 & $4 \%$ & 1 from 28 spot \\
Bilik 2 & 15.00 & $7 \%$ & 2 from 28 spot \\
& 09.00 & $0 \%$ & 0 from 9 spot \\
& 12.00 & $0 \%$ & 0 from 9 spot \\
Bilik 3 & 15.00 & $0 \%$ & 0 from 9 spot \\
& 09.00 & $0 \%$ & 0 from 4 spot \\
& 12.00 & $0 \%$ & 0 from 4 spot \\
& 15.00 & $0 \%$ & 0 from 4 spot \\
\hline \hline
\end{tabular}

TABLE 14.

DAYLIGHTING DISTRIBUTION (2ND STANDARD)

\begin{tabular}{cccc}
\hline \hline Room & Time & Value & Average : Minimum \\
\hline Laras-P & 09.00 & $1: 7,2$ & $25,21: 3,5$ lux \\
& 12.00 & $1: 4,2$ & $36,44: 8,5$ lux \\
& 15.00 & $1: 2,6$ & $26,81: 1$ lux \\
Bilik 1 & 09.00 & $1: 2,0$ & $20,05: 1$ lux \\
& 12.00 & $1: 22$ & $44,14: 2$ lux \\
& 15.00 & $1: 14$ & $14,05: 1$ lux \\
Bilik 2 & 09.00 & $1: 2,1$ & $2,1: 1$ lux \\
& 12.00 & $1: 1,3$ & $3,2: 2,5$ lux \\
& 15.00 & $1: 0,9$ & $0,9: 1$ lux \\
Bilik 3 & 09.00 & $1: 5,3$ & $28,75: 5,5 \operatorname{lux}$ \\
& 12.00 & $1: 5,6$ & $67,25: 12$ lux \\
& 15.00 & $1: 5,5$ & $11: 2$ lux \\
\hline \hline
\end{tabular}

Based on the first standard (Table 14), daylighting distribution in every room is not meet standard $40 \%$. It show that daylighting can not distibute well in LarasPematang room, Bilik 1 room, Bilik 2 room and Bilik 3 room. Based on the second standard (Table 15), LarasPematang room is meet standard at $15.00 \mathrm{PM}$, Bilik 1 at 09.00 AM, Bilik 2 is meet standard all day and Bilik 3 did not meet standard at all. In Laras-Pematang, Bilik 1 and Bilik 3 rooms, there are high illumination value near the openings that make contras between the area near the openings and area far from the openings. 
Factors affecting the high value of illumination outside building

\section{1) Latitude}

Balai Padang Adat is located in south of equator line at $2^{\circ}$, it can make this area receive high sun radiation all year. Outdoor illumination meassurement for 3 days and 3 times is very high because of this factor. Meanwhile, outdoor spot meassurement is located in front of the building. Orientation of the building is $315^{\circ}$ in NorthWest that can make the building receive high sun radiation all day in front, left and right of the building. Outdoor meassurement spot receive high illumination of the direct sunlight with 20.000-90.000 lux at 09.00 AM, 30.000100.000 lux at 12.00 AM and 10.000-30.000 at 15.00 PM.

\section{2) Altitude}

Meratus Highlands area is located in 450 meters above sea level. High outdoor illumination is also caused by this factors. In the tropics area, average illumination value is 10.000 lux, but in the field meassurement this research found minimum outdoor illumination value is $11.400 \mathrm{lux}$ at 15.00 PM. It show that this area has a high potention of daylighting.

\section{3) Cloud Cover}

Overcast sky has a $90 \%$ of cloud cover. Observation for 3 days show minimum cloud cover (Figure 6). At the first day and third day, cloud cover condition at 09.00 and 15.00 is $40-60 \%, 0-10 \%$, at 12.00 is $0-10 \%$. At the second day, cloud cover condition at 09.00 until 15.00 is 80 $100 \%$. Minimum cloud cover in this location can support latitude and altitude position and cause high outdoor illumination value up to 100.000 lux.

Factors affecting the low value of illumination outside building:

\section{Obstruction}

Obstruction affect ERC (External Reflected Component) and can reduce daylight level. Balai Padang Adat house has an obstruction in left, right and behind the building (Figure 8). In the left side, there is a building 0,4 to 1 meters from Balai Padang. In the right side, there is a building 2 to 3 meters from Balai Padang and there is a vegetation as an obstruction behind Balai Padang. Obstruction in left, right and behind side can eliminate daylight level in Bilik rooms. There is no obstruction in the front of building, so Laras-Pematang room which located in front of the building receive a daylight higher than Bilik room. But, daylight in Laras-Pematang room is eliminated by overhang.

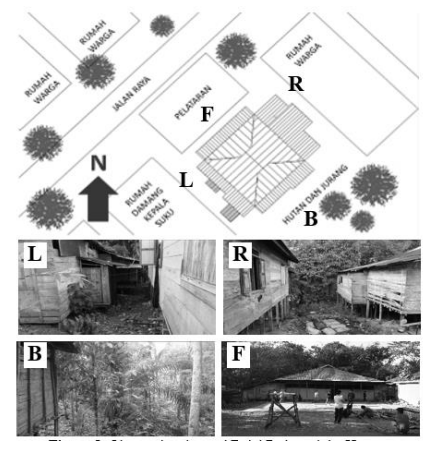

Figure 8. Obstruction Around Balai Padang Adat House

\section{Overhang}

Overhang is one of the design in tropical area. This building has an overhang on all sides because there is an opening alll side of the internal and external wall. Overhang can be devided into 2 type in this building, long overhang in Laras-Pematang room and short overhang in Bilik room. Laras-Pematang room has a big dimention of the openings but also has a 3 meters length of obstruction. Meanwhile, Overhang in Bilik room has a short dimention 0.3 to 0.5 meters length but also has a small dimention of the openings.

Overhang above the openings can reduce daylighting level. Overhang 0.7 meters can reduce $8 \%$ illumination and overhang 2.5 meters can reduce $25 \%$ illuminance [3]. flat overhang can also reduce $38 \%$ illuminance [10]. this factor affect poor daylighting performance.
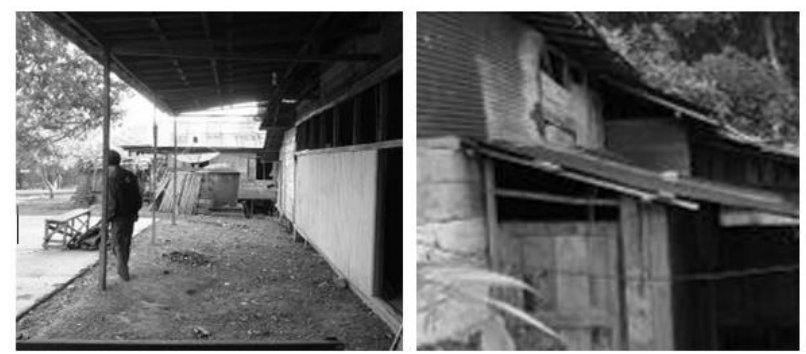

Figure 9. Overhang Condition. Long Overhang in Front of Building at Laras-Pematang Room (Left) and Short Overhang in Left,Rright anf Behind of Building at Bilik Rooms (Right)

3. Dimention of The Building

Dimention of building affect daylighting distribution inside the building [5]. Balai Padang Adat house has a total length of 20.2 meters, total width of 16.5 meters and total area of $262 \mathrm{~m}^{2}$. Balai Padang Adat house has a Laras-Pematang room as a centre of the activity and Bilik room as a secondary activity around the Laras-Pematang room. It has a double layer configuration that can make natural lighting from the openings can not enter to the centre room of this building. Related to this configuration, daylighting strategy that can applied to this building is top lighting. Balai Padang Adat do not have a opening on the roof as a toplighting strategy. Natural light can enter by openings on the wall and illuminate area around the openings (figure 11 to fogure 17).

4. Material Reflectance

Material reflectance is very important to distribute natural lighting inside the building. Sequence elements that affect the reflectance in the building are ceiling, wall and floor [5]. Balai Padang Adat house do not have a ceiling and have a high position of the roof. Material on the wall and the floor is bamboo or wood which has a dark colour and low material reflectance (Figure 3).

Material reflectance in Balai Padang adat house is 5$10 \%$ [5] in floor and wall. Low material reflectance affect IRC (Internal Reflected Component), so that high outdoor illumination value up to 100.000 lux can not enter maximum into the building. Illumination value in LarasPematang room show higher than Bilik 1, 2 and 3 because there are yellow and green colour of windonw in LarasPematang room.

\section{Opening Area}

Opening area is defined by WWR (Window to Wall Ratio. Geometry meassurement show that WWR less than $20 \%$ as a standart minimum WWR to get a good daylighting performance. All of the openings more than 
$20 \%$ of WWR in Laras-Pematang room. 3 from 8 openings more than $20 \%$ of WWR in Bilik 1 room. 2 from 7 openings more than $20 \%$ of WWR in Bilik 2 room. 2 from 4 openings more than $20 \%$ of WWR in Bilik 3 room.

Laras-Pematang room has a highest WWR $45 \%$ and there is no obstruction in there, but daylighting performance is poor because of long overhang 3 meters and large dimention of Laras-Pematang room. In another room, Bilik room has a small WWR 5-10\%.

Opening area is one of the important factor for daylighting performance as a sidelighting strategy [5]. Minimum WWR in Balai Padang Adat less than 20\% affect to the poor daylighting performance. There is a potention to increase opening area until WWR $20 \%$ based on the previous research [15].

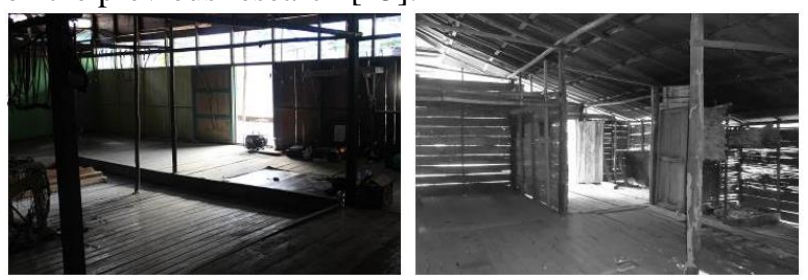

Figure 10. Opening area and position in Laras-Pematang room (Left), Bilik room (right) and material reflectance condition in floor and wall

\section{Opening Position}

Balai Padang Adat does not have window but openings between wall and roof. Opening position in this building is very high, 1.7 meters to 3.3 meters (Figure 10). This condition is not accordance with the previous research that give recomendation to opening position, upper openings less than 3 meters and lower openings more than work plan 1 meters [16]. opening position in Laras-Pematang room is 1.7 meters to 3.3 meters and opening position in Bilik room is 1.7 meters to 1.9 meters.

High openings is better to reach area far from the openings. In this case, opening position in every room is located behind the overhang. Large openings in LarasPematang room behind a long overhang 3 meters and small openings in Bilik room behind a small overhang 0.3 to 0.5 meters. There is no distance between upper of the openings to the lower of the overhang. It can reduce daylight enter from the openings and can not reach area far from the openings.
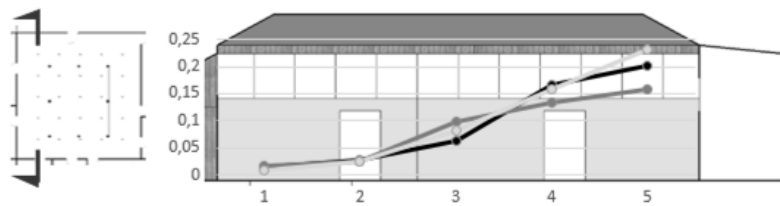

North-South Section of Daylight Factors on Laras-Pematang room
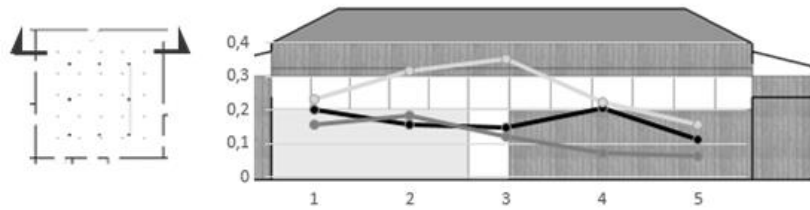

East-West Section of Daylight Factors on Laras-Pematang room
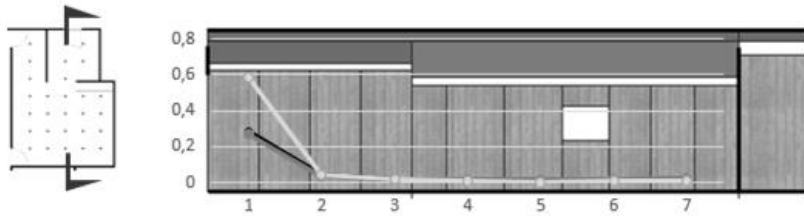

North-South Section of Daylight Factors on Bilik 1 room

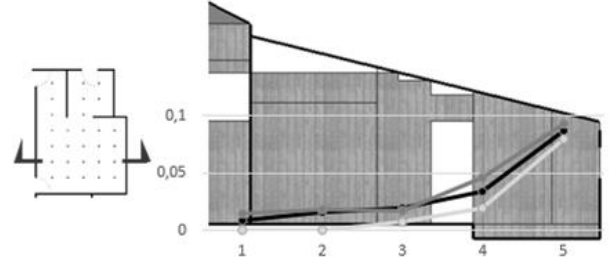

East-West Section of Daylight Factors on Bilik 1 room
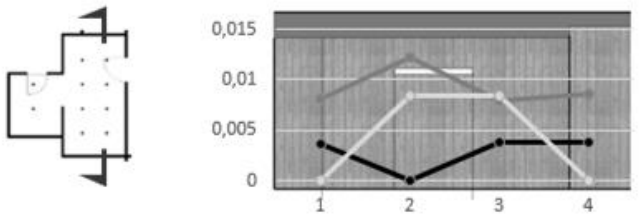

North-South Section of Daylight Factors on Bilik 2 room
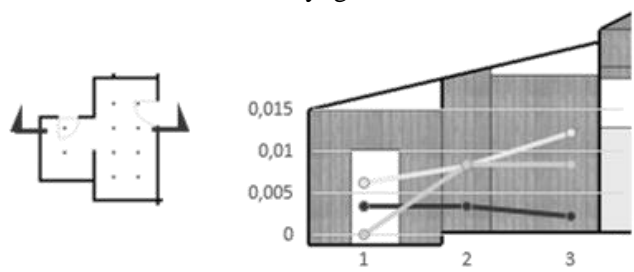

East-West Section of Daylight Factors on Bilik 2 room
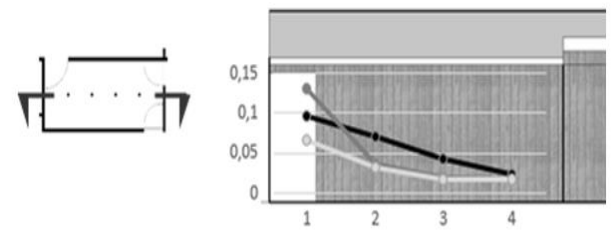

North-South Section of Daylight Factors on Bilik 3 room

$09.00 \mathrm{AM}=12.00 \mathrm{AM}=15.00 \mathrm{PM}$

Figure 11. Daylight Factor Profile

Daylighting performance in every room is shown in figure 11 related Daylight Factor profile from the area near the openings to the area far from the openings. NorthSouth Section of Daylight Factors on Laras-Pematang room show that datlight factor is not meet the standard, can not reach area in the south side and reduced in every meassurement spot (2 meters). East-West Section of Daylight Factors on Laras-Pematang room show that daylight factor increase in area near the door. Door as a part of the openings is important to increase daylighting performance related present occupant activity.

There is a window in Bilik 1 room. North-South Section of Daylight Factors on Bilik 1 room and East-West Section of Daylight Factors on Bilik 1 room show that effect of window to increasing daylight level is not too significant. Daylighting performance is better in 4 meters area from the openings.

North-South Section of Daylight Factors on Bilik 2 room and East-West Section of Daylight Factors on Bilik 2 room show that daylighting distribution in every meassurement spot is well because this room has a small dimention with openings around the wall that can enter daylight from the left, behind and front side from the outside.

Bilik 3 room is the smallest room in Balai Padang Adat house. North-South Section of Daylight Factors on Bilik 
3 room show that decreasing daylight factor is not significant compared to the Laras-Pematang room and Bilik 1 room which has a large dimention.

\section{CONCLUSION}

This research found that daylighting performance in Balai Padang Adat house was in poor quality. Large potention of daylighting outside the building can not acomodate daylighting inside the building related to the standart illumination value, daylight factor and daylighting distribution for present occupant activity. The design of Balai Padang Adat house need to changed to achieve comfort. Large dimention of the building, obstruction in left-reght-behind of Bilik room, niminum material reflectance, there is no distance between overhang and the openings, small opening area with WWR less than $20 \%$ and high position of the openings is factors that affect daylighting performance in this case.

Field meassurement did in august indicating clear sky condition because outdoor illumination value can reach 100.000 lux. Therefore, necessary to study in other months that show condition of the overcast sky 10.000 lux to identify daylighting performance.

This house is not recomended for the activity because it does not meet activity standard. This study recommends to be a change in building. Therefore, it is necessary to do research to identify the influence of factors that affect the daylighting performance in Balai Padang Adat house.

\section{ACKNOWLEDGEMENT}

The authors would like to acknowledge to Dayak Bukit Society as an occupant of Balai Padang Adat house. This research was funded by Denpasar Experimental Station For Traditional Housing Technology Development Research Institute for Human Settlement - Ministry of
Public Work at the field observation stage and Lembaga Pengelola Dana Pendidikan (LPDP) at the theses report.

\section{REFERENCES}

[1] Ander, Gregg D ,(1995), Daylighting Performance and Design John Wiley \& Sons, Inc, Canada.

[2] Egan, M.David dan Olgay, Victor W, (2002), Architectural Lighting, Second Edition, McGraw-Hill Company, NewYork.

[3] Evans, Benjamin H, AIA, (1981), Daylight in Architecture, McGraw-Hill, Inc, New York.

[4] Indrani, Hedy C, (2008), Kinerja Penerangan Alam pada Hunian Rumah Susun Dupak Bangunrejo Surabaya. Jurusan Arsitektur FTSP, Tesis ITS Surabaya.

[5] Koenigsberger dkk, (1973), Manual of Tropical Housing and Buildisfng. Bombay: Orient Longman, India.

[6] Littlefair, P, (2001), Daylight, Sunlight and Solar Gain in The Urban Environment, Vol. 70.3, hal 177-185.

[7] Lechner, Nobert, (2009), Heating, Cooling, Lighting, Sustainable Design Methods for Architects, Prestel, New York.

[8] Mangunwijaya, Y.B, (1994), Pengantar Fisika Bangunan. Jakarta: Djambatan.

[9] Muchamad, Bani Noor dkk. (2007). Anatomi Rumah Balai Adat Universitas Lambu Mangkurat dan Pustaka Banua, Banjarmasin.

[10] Prianto, E., \& Suyono, B. 2013. Simulasi Efisiensi Energi Listrik pada Bangunan Ber-Greenwall di Semarang. Semarang: JAFT Undip.

[11] SNI 03-2396-2001 (2001), Tata Cara Perancangan Sistem Pencahayaan Alami Pada bangunan Gedung, Diunduh dari www.ciptakarya.pu.go.id.

[12] SNI 03-6197-2000 tentang Konservasi Energi Sistem Pencahayaan pada Bangunan Gedung.

[13] Steffy, Gary, (2002), Architectural Lighting Design, John Wiley \& Sins, Inc, New York.

[14] Szokolay, S.V. (2004), Introduction to Architectural Science: The Basis for Sustainable Design 2nd Edition. Architectural Press, London.

[15] Urasa, (1998), Passive Cooling and Daylighting in Hot Humid Climates. The Association of Energy Engineers publications.

[16] Wirawan, Ratna Mulianingsih, (2007), Bukaan yang Efektif Untuk Pencahayaan Alami pada Rumah Tinggai di daerah Tropis Lembab, Jurusan Arsitektur FTSP, Tesis ITS Surabaya. 